\title{
Molluscan fauna of the lower reaches of the Syoyakha River (Yamal Peninsula)
}

\author{
YuV Bespalaya ${ }^{1}$, OV Aksenova ${ }^{1}$, NA Zubriy ${ }^{1}$ \\ 1 N. Laverov Federal Center for Integrated Arctic Research, Russian Academy of Sciences, Severnaya Dvina Emb. 23, 163000 (Arkhangelsk, Russian \\ Federation) \\ Corresponding author: Yulia Vladimirovna Bespalaya (jbespalaja@yandex.ru)
}

Academic editor: Aleksandr P. Novoselov • Received 14 May 2018 Accepted 24 July 2018 Published 3 August 2018

Citation: Bespalaya YuV, Aksenova OV, Zubriy NA (2018) Molluscan fauna of the lower reaches of the Syoyakha River (Yamal Peninsula). Arctic Environmental Research 18(2): 76-81. https://doi.org/10.3897/issn2541-8416.2018.18.2.76

\begin{abstract}
The molluscan fauna of the Syoyakha (Zelenaya) River remain poorly explored even though the Syoyakha is one of the biggest rivers on the Yamal Peninsula. The Syoyakha River is remarkable for its high fish stocking capacity and it plays an important role in the seasonal distribution and migration of commercial fish species. Freshwater mollusks are known to be a major component of freshwater ecosystems and they make up a part of the diet of many commercially important fish species. The species composition of the mollusks inhabiting the lower reaches of the Syoyakha River has been studied. Five bivalve species of the family Sphaeriidae were found, namely Sphaerium corneum (Linnaeus, 1758), Pisidium casertanum (Poli, 1791), P. globulare (Clessin in Westerlund, 1873), P. lilljeborgi (Clessin in Esmark et Hoyer, 1886) and P. dilatatum (Westerlund, 1897). In general, the molluscan fauna of the lower reaches of the Syoyakha River are taxonomically poor, which can be considered typical of freshwater invertebrate communities living at high latitudes. Another reason for the decline in species diversity may lie in the absence of any large transit watercourse in the basin in question allowing northward dispersion of the mollusks. The average density of mollusks in the watercourse stretch under study varied from $98.9 \mathrm{ind} . / \mathrm{m}^{2}$ to $620.5 \mathrm{ind} . / \mathrm{m}^{2}$. P. globulare settlements had the highest recorded density of $1,442.9 \mathrm{ind} . / \mathrm{m}^{2}$. The mollusks are confined to clayey, silty and sandy substrates with remnants of vegetation. The fauna is basically formed by widespread Palearctic and Holarctic mollusk species that have adapted to the extreme conditions of the Arctic. The findings may be used for hydrobiological and fishery characterization of the watercourse given that the recorded species of S. corneum, P. globulare, P. lilljeborgi, and P. dilatatum are a major food item for important fish species, such as cisco, vendace, char, muksun, etc.
\end{abstract}

\section{Keywords}

Yamal Peninsula, freshwater mollusks, Sphaeriidae, species diversity, Syoyakha River, Arctic.

Copyright Bespalaya YuV et al. This is an open access article distributed under the terms of the Creative Commons Attribution License (CC-BY 4.0), which permits unrestricted use, distribution, and reproduction in any medium, provided the original author and source are credited. 


\section{Introduction}

The ecosystems of the Yamal Peninsula are subject to an intensive anthropogenic influence connected with construction and operation of gas fields (Golovatin et al. 2010), hence there is a need to perform environmental monitoring in order to control these negative effects on water ecosystems (Bogdanov et al. 2012). Freshwater mollusks are an important component of freshwater ecosystems and they often dominate in benthic communities (Sousa et al. 2011). Further, mollusks also make up a part of the diet of many commercially important fish species (Leshko 1998).

The first data concerning the composition of the molluscan fauna of water reservoirs on the Yamal Peninsula come from materials collected by the expedition that was organized by the Kuznetsov brothers in 1909 (Lindholm 1919). In the summer of 1964, the scientific research expedition of the ichthyological team of the Biology Institute of the Urals Branch of the USSR Academy of Sciences collected mollusks in the basin of the Syoyakha River (Khokhutkin 1966). New data on the species composition of freshwater mollusks were obtained later, during the study of the diet of fish species inhabiting the Yarroto, Neito and Polkurto water reservoirs (Khokhutkin 1969). A total of 16 species of freshwater mollusks were recorded on the peninsula (Khokhutkin 1969).

Many years of research studies of the freshwater mollusks of the Yamal Peninsula inhabiting the Yuribei River and Lake Yarroto that were undertaken by V.N. Dolgin (2001) are noteworthy among contemporary works in the literature. The gastropod fauna of the Schuchya River were studied in 2011 (Palatov and Vinarski 2012). The macrozoobenthos, including the freshwater mollusks inhabiting a number of watercourses in Southern Yamal, has been evaluated (Palatov and Chertoprud 2012). The zoobenthos of water reservoirs and watercourses of the Setnaya, Ngoyakha and Yaroyakha Rivers that are located on the south-eastern part of the peninsula has been studied. The taxonomic composition of the invertebrate bottom fauna has been analyzed (Stepanov 2016, 2017).

However, the molluscan fauna of the Syoyakha (Zelenaya) River remain poorly explored even though the Syoyakha is one of the largest rivers of the
Yamal Peninsula. The watercourse is $165 \mathrm{~km}$ long and the watershed covers an area of 4,400 $\mathrm{km}^{2}$ (Bolshakov et al. 1995). The Syoyakha River is remarkable for its high fish capacity and plays an important role in the seasonal distribution and migration of commercial fish species (Bogdanov et al. 2000).

The goal of this research was to study the fauna and to analyze the zoogeographical structure of the molluscan fauna in particular in the lower reaches of the Syoyakha (Zelenaya) River.

\section{Materials and methods}

The Yamal Peninsula is located the Northern part of Western Siberia in the central part of Russia. The Yamal Territory refers to the West Siberian plain (Morozova and Magomedova 2004). The surface dismembered quite strongly by valleys of the rivers, streams and lake hollows (Golovatin et al. 2009). The summers are short and cold, and the winters are windy and frosty. The average annual temperature in the South of Yamal (Salekhard) is $-6.6^{\circ} \mathrm{C}$, and on the northern side it is -10.2 ${ }^{\circ} \mathrm{C}$ (Morozova and Magomedova 2004). The peninsula is located in the permafrost zone (Dobrinsky 1995).

The mollusk samples of the Yamal Peninsula were collected in the lower reaches of the Syoyakha (Zelenaya) River in July-August 2014 (Fig. 1). The Syoyakha is a plain river type with a low flow rate and its bed meanders strongly in the shallow and broad valleys (Dobrinsky 1995). The river originates from Lake Yambuto and runs into Obskaya Bay of the Kara Sea. Ice on most Yamal rivers is most likely to form in the second week of October (Dobrinsky 1995). The temperature dynamics in the Syoyakha River were measured at 60-minute intervals using TP-1 temperature data loggers (TermoReg version 2.01.) between July 15, 2014 and August 30, 2014.

The benthic samples were collected using standard methods (Mordukhay-Boltovskoy 1975). Samples were washed using a hydrobiological sieve. The mollusks were fixed in 96\% ethanol (Mordukhay-Boltovskoy 1975). A total of 1,886 mollusk specimens were collected.

The mollusks were identified according to a number of keys (Korniushin 1996, 2001; Glöer and Meier-Brook 2003). The justification of applying the 

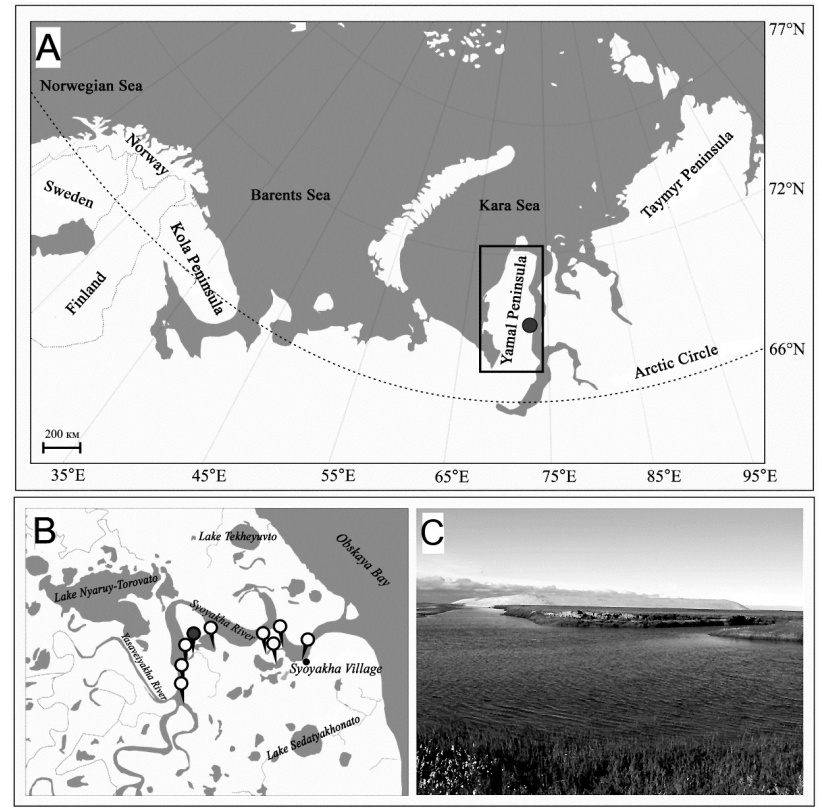

Fig. 1. The schematic sampling site map of the study area: A - the schematic study area map, B - sampling sites (the white markers correspond to blank samples (no mollusks found), the grey marker corresponds to samples in which mollusks were found), C - view of the Syoyakha River

traditional approach to determining genera within the Sphaeriidae family is provided by Bespalaya et al. (2017). Five major monophyletic lineages were originally assigned by Lee and Ó Foighil (2003) as genera: Sphaerium, Pisidium s. str., Cyclocalyx, Odhneripisidium, and Afropisidium. These were subsequently adopted by other phylogenetic studies on Sphaeriidae, but us subgenera (e.g., Clewing et al. 2013; Bößneck et al. 2016; Bespalaya et al. 2017). In some works, the phylogeny of Lee and O'Foighil
(2003) was taken into account, but the genus Cyclocalyx Dall, 1903 has been replaced by Euglesa, Jenyns, 1832 following the principle of priority of publication (Gargominy et al. 2011; Bogatov and Prozorova 2017).

The specimens are kept in the collection of the Russian Museum of Biodiversity Hotspots (RMBH) of the N. Laverov Federal Center for Integrated Arctic Research, Russian Academy of Sciences (FCIARtic).

\section{Results}

The hydrochemical characteristics of the waters in the Syoyakha River are presented in Table 1. The waters in the river are weakly mineralized; the basic ion concentration is low. The average water temperature in the Syoyakha River during the study period varied between $6.9^{\circ} \mathrm{C}$ and $11.9^{\circ} \mathrm{C}$.

Fives mollusk species of the Sphaeriidae family were found in the lower reaches of the Syoyakha River during the present study (Fig. 2). The bivalve community was dominated by Pisidium globulare (Westerlund, 1873) (36.9\%), P. lilljeborgi ranked second (Clessin in Esmark et Hoyer, 1886) (31.9\%). The average density of mollusks varied between 98.9 ind. $/ \mathrm{m}^{2}$ and 620.5 ind. $/ \mathrm{m}^{2}$ (Table 2). The P. globulare settlements had the highest recorded density of $1,442.9 \mathrm{ind} . / \mathrm{m}^{2}$. The mollusks are confined to clayey, silty and sandy substrates with remnants of vegetation. The fauna of mollusks of the lower reaches of the Syoyakha River include the European and Western Siberian, Palearctic, Holarctic, and Cosmopolite species (Table 2).

Table 1. Species composition and relative abundance of mollusk species in the Syoyakha River samples (Yamal Peninsula). Geographic distribution: PA - Palaearctic, H - Holarctic, C - Cosmopolite, EWS - Europe, Western Siberia.

\begin{tabular}{|c|c|c|c|c|c|}
\hline \multirow[b]{2}{*}{ Species } & \multirow[b]{2}{*}{$\begin{array}{l}\text { Geographic } \\
\text { distribution }\end{array}$} & \multicolumn{4}{|c|}{ Syoyakha River } \\
\hline & & $\begin{array}{c}\text { Average density (ind./ } \\
\left.\mathbf{m}^{2}\right) \pm S D\end{array}$ & $\begin{array}{c}\text { Density, (ind./m²) min- } \\
\max \end{array}$ & $\mathrm{N}$, ind. & $\mathrm{N}, \%$ \\
\hline Sphaerium corneum (Linnaeus, 1758) & PA & $164.8 \pm 125.3$ & $14.3-435.7$ & 300 & 15.9 \\
\hline Pisidium casertanum (Poli, 1791) & $\mathrm{C}$ & $257.1 \pm 175.4$ & $107.1-450.0$ & 108 & 5.7 \\
\hline P. globulare (Clessin in Westerlund, 1873) & EWS & $620.5 \pm 504.1$ & $71.4-1442.9$ & 695 & 36.9 \\
\hline P. lilljeborgi (Clessin in Esmark et Hoyer, 1886) & $\mathrm{H}$ & $391.6 \pm 419.4$ & $7.1-978.6$ & 603 & 31.9 \\
\hline P. dilatatum (Westerlund, 1897) & $\mathrm{PA}$ & $98.9 \pm 119.4$ & $14.3-450.0$ & 180 & 9.5 \\
\hline Total & & & & \multicolumn{2}{|c|}{1.886} \\
\hline
\end{tabular}

Note: $N$, ind. - number of individuals representing the species in the collection, $N, \%$ - proportion of individuals representing the species in the collection, $S D$ - standard deviation. 
A

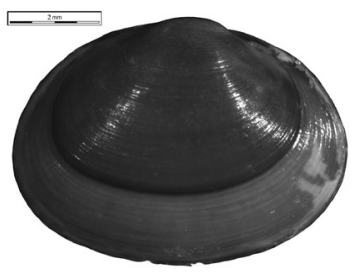

B

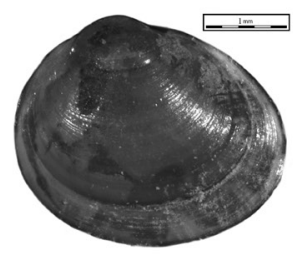

C

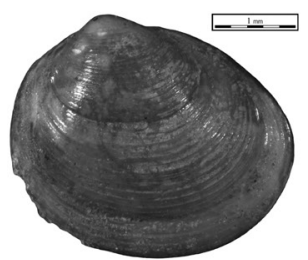

D

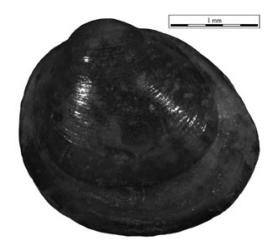

E

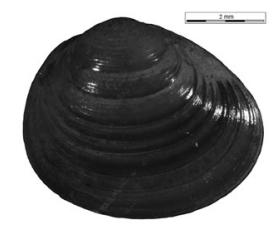

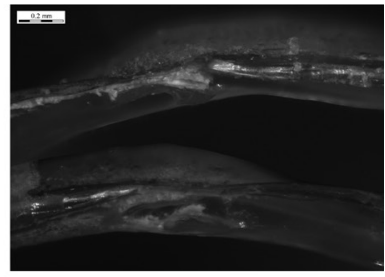
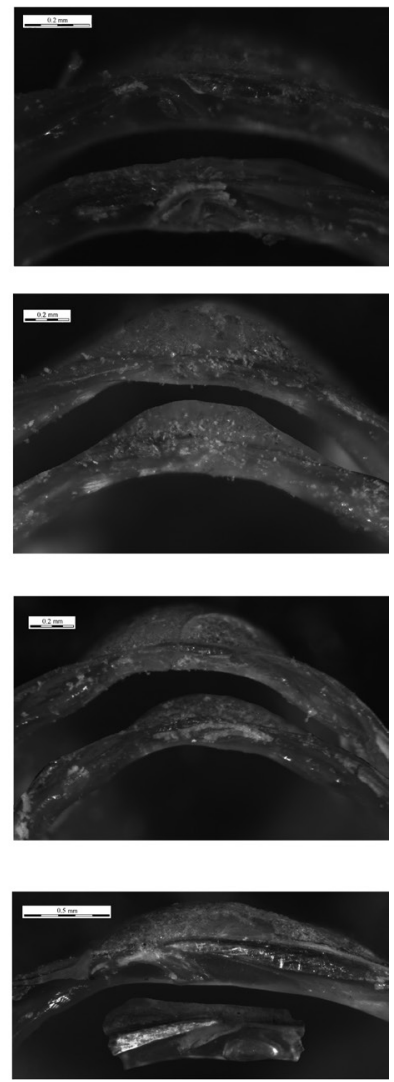

Fig. 2. The external morphology of the shell (left), beak and hinge of the right and left valves (right) of mollusks from the lower reaches of the Syoyakha River: A - Sphaerium corneum, B - Pisidium casertanum, C - P. globulare, $\mathrm{D}-$ P. lilljeborgi, E - P. dilatatum

Table 2. Hydrochemical characteristics of the Syoyakha River (Yamal Peninsula, July-August 2014)

\begin{tabular}{cc}
\hline Parameters & Syoyakha River \\
\hline $\mathrm{K}^{+}(\mathrm{mg} / \mathrm{l})$ & $0.53 \pm 0.08$ \\
$\mathrm{Na}^{+}(\mathrm{mg} / \mathrm{l})$ & $2.8 \pm 0.2$ \\
$\mathrm{Mg}^{2+}(\mathrm{mg} / \mathrm{l})$ & $1.2 \pm 0.09$ \\
$\mathrm{CI}^{-}(\mathrm{mg} / \mathrm{l})$ & $3.54 \pm 0.3$ \\
$\mathrm{SO}_{4}^{2-}(\mathrm{mg} / \mathrm{l})$ & $1.12 \pm 0.08$ \\
$\mathrm{Ca}^{2+}(\mathrm{mg} / \mathrm{l})$ & $2.2 \pm 0.2$ \\
\hline
\end{tabular}

\section{Discussion}

In general, the molluscan fauna of the lower reaches of the Syoyakha River are taxonomically poor compared to the watercourses in both the southern part of Western Siberia (Palatov and Vinarski 2012) and the subarctic zones of the tundra (Bolotov et al. 2014, Bespalaya et al. 2017). The environmental conditions in the Arctic are extreme for invertebrates (Chernov 2012). This is due to the low temperatures, high level of UV radiation and a content of organic and mineral substances that is often insufficient (Samchyshyna et al. 2008, Rautio et al. 2011). Another reason for the decline of the species diversity may lie in "the absence of any large transit watercourse in the basin in question allowing northward dispersion of the molluskcs" (Palatov and Vinarski 2012: p.160). It is noteworthy that, in our samples no gastropod species were found. Our data are in accordance with Khokhutkin (1966), who also did not discover mollusks of this class in the Syoyakha River. At the same time and by the same author the Gyraulus acronicus and Aplexa elongata were recorded in the swamps of the Syoyakha River basin (Khokhutkin 1966). As a whole, several species of gastropod were registered in the reservoirs of Middle and Northern Yamal (Dolgin 2001, Stepanov $2016,2017)$ and twenty species were registered on the Southern Yamal (Palatov and Vinarski 2012).

The reasons for the absence of the gastropod species in the investigated part of the river will require additional studies. It can be assumed that in the lower reaches of the Syoyakha River provide an unsuitable habitat for gastropods.

In general, the bivalves from Syoyakha River are widespread in the Holarctic and Palearctic regions (Table 1). According to data in the literature, the Sphaeriidae family often dominate in high-latitude water reservoirs (Ashworth and Preece 2003, Bespalaya 2014). Consequently, it was established that $P$. casertanum and P. globulare were dominated in the lakes of the Vaigach Island (Bespalaya 2014, Bespalaya et al. in press). The data also conform to the observations of Dolgin (2001), who notes that $P$. dilatatum, $P$. globulare and P. lilljeborgi are most abundant in the Arctic. Some authors believe that the Sphaeriidae are 
adapted to low temperatures (Ashworth and Preece 2003, Guralnick 2005), which is why they inhabit the Arctic water reservoirs.

\section{Conclusion}

According to our records, the molluscan fauna of the Syoyakha River are represented by five species of freshwater bivalves of the Sphaeriidae family. The bivalves of the Syoyakha River are widespread Palearctic and Holarctic mollusk species that have adapted to the conditions at high latitudes. The results of research may be used for hydrobiological and fishery

\section{References}

- Ashworth AC, Preece RC (2003) The first freshwater molluscs from Antarctica. Journal of Molluscan Studies 69: 89-92. https://doi.org/10.1093/mollus/69.1.89

- Bespalaya YV (2014) Molluscan fauna of an Arctic lake dominated by a cosmopolitan Pisidium species. Journal of Molluscan Studies 81: 294-298. https://doi.org/10.1093/mollus/ eyu081

- Bespalaya YV, Aksenova OV, Bolotov IN, Kondakov AV, Kogut YE (2017) Freshwater molluscan fauna of the coastal lowlands of the Pechora Sea (Bolshezemelskaya tundra, Nenets Autonomous Area) Fauna of the Urals and Siberia 1:25-32.

- Bogatov VV, Prozorova LA (2017) Taxonomy and diversity of freshwater bivalves (Bivalvia) of China (on the basis of analysis catalog Heat Zhuang 2013). Zoologicheskii Zhurnal 96(2): 153-171.

- Bogdanov VD, Bogdanova EN, Goskova OA, Melnichenko IP (2000) Retrospective ichthyological and hydrobiological studies in Yamal. Ekaterinburg Publishers, Ekaterinburg, 88 pp.

- Bogdanov VD, Bogdanova EN, Melnichenko IP, Stepanov LN, Yarushina MI (2012) Problems of the protection of bioresources development of the Bovanenkovo gas condensate. Economy of the Region 4: 68-79. https://doi.org/10.17059/2012-4-5

- Bolotov IN, Bespalaya YuV, Aksenova OV, Gofarov MYu, Sokolova SE (2014) Molluscs in the zoobenthos of relict lakes with abnormally high biological production in the eastern European Subarctic. Inland Water Biology 7: 61-71. https://doi. org/10.1134/S1995082914010040

- Bößneck U, Clewing C, Albrecht C (2016) Exploring high-mountain limnic faunas: discovery of a novel endemic characterization of the watercourse given that the recorded species of Sphaerium corneum, Pisidium globulare, $P$. lilljeborgi, and $P$. dilatatum are a major food item for commercially important fish species, such as cisco, vendace, char, muksun, etc. (Dolgin 2001).

\section{Acknowledgements}

This research was supported by the Program of the Presidium of the Urals Branch of the Russian Academy of Sciences No. 0409-2018-0148) and grant No. 17-44-290016 p_a of the Russian Foundation for Basic Research. bivalve species (Sphaeriidae: Pisidium) in the Nepal Himalayas. Invertebrate Systematics 30: 588-597.

- Chernov YuI (2012) The Arctic through the eyes of the biologist. Priroda 2: 47-56.

- Clewing C, Bössneck U, von Oheimb PV, Albrecht C (2013) Molecular phylogeny and biogeography of a high mountain bivalve fauna: the Sphaeriidae of the Tibetan Plateau. Malacologia 56: 231-252. https://doi.org/10.4002/040.056.0213

- Czernyadjeva I (2001) Moss flora of the Yamal Peninsula (West Siberian Arctic). Arctoa 10: 121-150. https://doi. org/10.15298/arctoa.10.13

- Dobrinsky LN (1995) The nature of Yamal. Nauka, Ekaterinburg, $436 \mathrm{pp}$.

- Dolgin VN (2001) Freshwater molluscs of the subarctic and arctic regions of Siberia: DSc (biology) dissertation. Tomsk, 2001.

- Gargominy O, Prie V, Bichain JM, Cucherat X, Fontaine B (2011) Liste de référence annotée des mollusques continentaux de France. MalaCo $11: 307-382$.

- Glöer P, Meier-Brook C (2003) Süsswassermollusken. Ein Bestimmungschlüssel für die Bundesrepublik Deutschland. 13 Auflage. Hamburg: Deutscher Jugendbund für Naturbeobachtung, $134 \mathrm{pp}$.

- Golovatin MG, Morozova LM, Ektova SN, Paskhalny SP (2010) The change of tundra biota on the Yamal Peninsula (North of Western Siberia, Russia) in connection with anthropogenic and climatic shifts. In: Gutierrez B, Pena C (Eds) Tundras: Vegetation, Wildlife and Climate Trends. Nova Science Publishers, Inc. New York, 1-46. 
Guralnick RP (2005) Combined molecular and morphological approaches to documenting regional biodiversity and ecological patterns in problematic taxa: a case study in the bivalve group Cyclocalyx (Sphaeriidae, Bivalvia) from western North America. Zoologica Scripta 34: 469-482. https://doi. org/10.1111/j.1463-6409.2005.00205.x

- Khokhutkin IM (1966) Some data on the malacofauna of the Yamal and Tazov Peninsulas. In: Pomerancev GP (Ed.) Biology of commercial fish species of the Nishnyaya Ob River. Materials of the Biology Institute of the Ural Branch of the USSR Academy of Sciences, Sverdlovsk, 65-66.

- Khokhutkin IM (1969) New data on the freshwater malacofauna of the Yamal Peninsula. Siberian Malacology Issues: Interuniversity scientific-methodical conference on mollusc studies. Tomsk University press, Tomsk, 56-57.

- Korniushin AV (1996) Bivalve molluscs of the superfamily Pisidioidea in the Palaearctic region: fauna, systematics, phylogeny. Schmalhausen Institute of Zoology, Kiev, 176 pp.

- Korniushin AV (2001) Taxonomic revision of the genus Sphaerium sensu lato (Bivalvia: Sphaeriidae) in the Palaearctic Region, with some notes on the North American species. Arch Molluscenkd 129: 77-122. https://doi.org/10.1127/arch. moll/129/2001/77

- Lee T, Ó Foighil D (2003) Phylogenetic structure of the Sphaeriinae, a global clade of freshwater bivalve molluscs, inferred from nuclear (ITS-1) and mitochondrial (16S) ribosomal gene sequences. Zoological Journal of the Linnean Society 137: 245-260 https://doi.org/10.1046/j.1096-3642.2003.00047.x

- Leshko YV (1998) Molluscs. Nauka, St Petersburg, 168 pp.

- Lindholm WA (1919) Über Binnenmollusken aus dem äusersten Nordwesten Sibirien. Scientific results of the brothers Kuznetsov Expedition to the Polar Urals under command of O.O. Backlund in 1909, 10:1-10.
- Mordukhay-Boltovskoy FD (1975) Metodika izucheniya biogeotsenozov vnutrennikh vodoemov [Method of studying the biogeocenoses of inland water bodies]. Moscow.

- Morozova L, Magomedova M (2004) The structure of the vegetation cover and plant resources of the Yamal Peninsula. Ural University Publishing, Yekaterinburg, 63 pp.

- Palatov DM, Vinarski MV (2012) Materials on freshwater gastropoda fauna of the Schuchya River basin (the Southern Yamal). Estestvennie nauki i ecologia 16: 154-162.

- Palatov DM, Chertoprud MV (2012) Rheophilic fauna and invertebrate communities of the tundra zone: A case study of the Southern Yamal. Inland Water Biology 5(1): 19-28.

- Rautio M, Dufresne F, Laurion I, Bonilla S, Vincent WF, Christoffersen KS (2011) Shallow freshwater ecosystems of the circumpolar Arctic. Ecoscience 18: 204-222. https://doi. org/10.2980/18-3-3463

- Samchyshyna L, Hansson LA, Christoffersen K (2008) Patterns in the distribution of Arctic freshwater zooplankton related to glaciation history. Polar Biology 31:1427-1435. https://doi.org/10.1007/s00300-008-0482-4

- Sousa R, Ilarri M, Souza AT, Antunes C, Guilhermino L (2011) Rapid decline of the greater European pea clam at the periphery of its distribution. Annales de Limnologie - International Journal of Limnology 47: 211-219. https://doi.org/10.1051/ $\operatorname{limn} / 2011041$

- Stepanov LN (2016) The diversity of zoobenthos of water reservoirs and watercourses of the Setnaya and Ngoyakha River basins (Yamal Peninsula, Yamalo-Nenets Autonomous Area). Fauna of the Urals and Siberia 1: 90-104.

- Stepanov LN (2017) Zoobenthos of water reservoirs and watercourses of the Yarayakha River basin (Southern Yamal, Yamalo-Nenets Autonomous Area) Fauna of the Urals and Siberia 1: 116-130. 